\title{
Perceptions of reading of children with comprehension difficulties
}

Maniotes, Leslie K

International Association of School Librarianship. Selected Papers from the ... Annual Conference; 2001;

\section{Perceptions of Reading of Children with Comprehension Difficulties}

\author{
LESLIE K. MANIOTES \\ University of Colorado, Boulder, \\ Golden, CO 80403, USA \\ Leslie.maniotes@colorado.edu
}

\begin{abstract}
This study addresses the question of how students with comprehension problems perceive reading. The subjects of the study are eight to ten-year-old students from the South Eastern United States. Students' reading comprehension was assessed and interviews were used to elicit perceptions of reading. The results suggest that these students see reading as a school-related task rather than something for enjoyment or entertainment. The report includes three case studies elaborating on the diversity and depth of individual children. A final discussion considers what school librarians can do to help children become aware of purposes for reading as making meaning.
\end{abstract}

\section{Perceptions of reading of children with comprehension difficulties}

What is reading? "Something (to do) so you can get good at reading." These are the remarks of a third grader struggling with reading comprehension. Why do you read? "I read so I can be a better reader!" Do children who are struggling with comprehension have views about reading that can help us understand parts of their struggles? How can their notions about reading help us to open the exhilarating world of print?

Many young children in the primary grades have been identified with comprehension difficulties in reading. The causes of these difficulties are not yet fully understood although there has been considerable speculation. The children's perceptions of the purpose of reading may shed light on the underlying causes of these difficulties.

This exploratory study addresses the question of how students with comprehension problems perceive reading. What do they view as the purpose of reading? Do they view reading as an essential meaning-making vehicle in their lives? Or do they view reading merely as a school-related skill? The purpose of this study was to get a detailed picture of the perceptions of reading of young children who had been identified with comprehension difficulties.

In this paper I will begin with background on children's perceptions of reading and links to comprehension. Next, I will define the assessment I used to inform my understanding of the students' comprehension difficulties. I will then characterize the general results of the assessment and interview for all the students. Finally, I will discuss three students in depth. These cases illustrate the complexities and individuality of comprehension difficulties, and include a variety of methods that could be included to enhance how parents, the community and library programs might support literacy learning. 
The literature on student's perceptions of reading concentrates on comparing good readers perceptions to poor readers. These types of studies date back to the fifties when Edwards looked at students' understandings of reading (Edwards, 1958). He found differences between good readers and poor readers perceptions of reading. In that study good readers related reading to comprehension while poor readers related reading to decoding words. Johns (1974) also concluded that good and poor readers had different definitions for reading. Johns and Ellis (1975) looked at 1600 students' perceptions of reading in kindergarten through seventh grade. The interviews showed that an integrated understanding of reading involving both decoding and meaning did not surface until seventh and eighth grade. The older students had a more developed understanding of reading. The evidence in this study suggests a continuum from understanding reading as having to do simply with decoding, to describing it as a mixture of word decoding and meaning. These studies linked students' perception with general reading achievement, but made no link to student's ability to comprehend or make meaning. This study focuses on how their understanding of the task of reading may inform their meaning making process.

Comprehension in itself is a complex task. Cunningham (1993) describes the complexity of comprehension in asserting that there are three key parts in comprehension. In Miller and Yochum's research (1991) the students with comprehension problems were unaware of their own reading difficulties. Not being aware of their difficulties shows us a possible lack of understanding of the task of reading.

When we think about how we can help children who have limiting perceptions of reading we can gain hope from the findings of Harste (1978). His study suggests that teachers' theoretical stance had an effect on students' perceptions of reading. Borko and Eisenhart (1986, p. 607) found, "differing conceptions of reading that good and poor readers hold are related to differences in their learning-to-read experiences." In other words the experiences that we provide children may have an impact on how they perceive reading, which seems to have a difference in their performance and success as readers.

This body of research of student's perceptions of reading is varied and suggests that people working with children can influence the student's perceptions of reading. It also points to the fact that students are not always aware of their own problems in reading, but that they do have ideas about what reading is. As good readers have a more sophisticated understanding of reading than poor readers, it might be that if we structure literacy events around building a well rounded concept reading it may make reading more meaningful for struggling readers. This study attempts to expose student's perceptions about reading for students who are struggling with comprehension in second and third grades.

\section{Gathering Information}

When I asked second and third grade teachers from an elementary school in the southeastern United States for names of children with comprehension difficulties, they had no problems coming up with names. The teachers were enthusiastic because I was going to assess these children and help them develop individualized plans for these students' reading instruction. It had been mandated that the teachers implement an individual reading plan for all students below grade three who were not yet reading on grade level. The teachers wanted the assessments to inform their teaching but they did not know where to start. I was offering to help them find a useful assessment and a way to interpret the information to guide their instruction. 
At the teachers' request, I met with each child for three 20 minutes sessions, to assess their level of reading comprehension and to draw out their perceptions of reading. I chose three methods of data collection: running records of oral reading (Clay, 1993), reading inventory assessments and structured interviews. I used the Qualitative Reading Inventory-II (QRI-II) to assess the children's comprehension level (Leslie \& Caldwell, 1995). I also adapted interview questions from the Burke Reading Inventory to elicit the children's perceptions of reading (Burke, 1977).

My analysis of the children's reading comprehension incorporated three components; running records of oral reading, and assessments of comprehension for listening and oral reading passages. The children read two texts orally, one narrative text and one expository text, on their instructional level. A detailed analysis of the running record of oral reading provided data on missing punctuation, omitted lines of text, and strategies applied in reading as evidence of how the children comprehended what they read.

I then read two listening passages to the children, one narrative text and one expository text, at their grade level. For each of the oral reading and listening passages, I used the children's retellings to define what the students recollected from texts. In addition, I worked with an independent reviewer to score and analyze, the running records and the retellings to establish inter-rater reliability.

Finally, I conducted structured interviews with each student. The interviews were used to capture the children's perceptions of the reading process. I recorded detailed field notes during each interview. The interviews included the following questions:

- What do you like about reading?

- Why do you think people read?

- Why do you read?

- What would you say reading is?

\section{$\underline{\text { General Results }}$}

Analyzing Running Records for understanding comprehension. Typically a running record of oral reading is used with beginning readers to determine text level. I found that a running record of oral reading can be a valuable tool for children at any age having difficulties with reading. The running record offers a window into the child's processing of text, which can inform how the child is decoding, comprehending and processing text. Specifically, looking at comprehension through an analysis of the running record, certain strategies which good readers use to make meaning were missing in the processing of these children. The strategies missing which showed lapses in comprehension were; using natural breaks in language and punctuation to read meaningful units of text, monitoring for meaning, and self-correction rates between 1:2 and 1:4. A high self-correction rate can show that the reader was willing to let mistakes go uncorrected. Although fluency and phrasing are not actually a part of the regular conventions of running records (Clay, 1993), a careful observer notes these behaviors in oral reading during a running record can be extended by taking note of ignored periods and punctuation.

The results of the comprehension analysis verified the teacher's initial identification of these children as having comprehension difficulties. For example, in the two oral reading 
passages for the running records at the children's instructional level, fifteen of the eighteen students read through punctuation marks showing a weakness in reading meaningful units and fluency. Eleven of the eighteen omitted entire lines of text without monitoring for meaning or self-correcting. All the students had poor self-correction rates on at least one of the two readings ranging from 1 : nil through 1:16. Six had a good self-correction rate (i.e. $1: 1$, or $1: 2$ ) in the narrative text reading only.

Analyzing comprehension through retellings of oral and listening passages. Comprehension is a complex process involving many components (Cunningham, 1993). In order to understand the possible components of why these students were not able to comprehend what they read, I used two types of retellings. The assessment included retellings of oral reading passages at the students' instructional level, and retellings in a listening task on passages at the students' grade level. Through looking at retellings of reading and listening passage I could compare the results to get an overall picture of what the child could relate back to me from texts. All children's retellings were scored on a rubric from one to four. All of the children scored below average on most of the retellings showing that comprehension is a true struggle for each of the students.

Interviews as a means of assessment of student's perceptions of reading. The interviews showed that most all of the children viewed reading as something that they had to do while a few showed some evidence that it could be for enjoyment or enrichment. Children's responses to the questions showed that they mainly read because they feel it helps them become a better reader. One child's description of what reading is, illustrates the importance of reading as a skill. She describes reading as, "A way to get better at it." This similar feeling about reading was described in many different ways through the children's interviews. The majority of these children having troubles with comprehension saw reading as a skill or an activity in school that they had to get better at.

Table 1

\begin{tabular}{lccc}
\hline \multicolumn{1}{c}{ Question } & Read to & $\begin{array}{c}\text { Read for } \\
\text { enjoyment or } \\
\text { enrichment }\end{array}$ & $\begin{array}{c}\text { Response did } \\
\text { not answer the } \\
\text { question }\end{array}$ \\
\hline What do you like about reading? & 10 & 8 & 0 \\
Why do you think people read? & 13 & 4 & 1 \\
Why do you read? & 14 & 3 & 1 \\
What would you say reading is? & 8 & 0 & 9 \\
\hline
\end{tabular}

Although this chart seems to show quite a few of the children saw reading as enjoyable, the entire interview made it clear that all of the children perceived reading as a skill. The majority of the responses were that reading was a school related skill. Some responses were mixed, with an emphasis on school related work. No one child gave the sole impression that reading was a enjoyable task in itself.

Generally the children saw reading as a skill that had to be mastered as an end in itself. The evidence from the interviews shows that these children are aware of the how to, but not the what for, of reading. These general results show trends in this group of children, but the real picture that describes the individual realities of these children's understanding of 
reading and how that affects their comprehension can only be described in detail through individual cases.

The following three cases show the complexity of readers and the task of comprehension. Perception of reading seems to factor in as something important to note for students who are having difficulties with comprehension, but it is by no means an answer to their difficulties. These cases show the complexities in the individuals and some possible approaches that may help these students gain a broader perspective on what reading can be.

\section{Three Case Studies}

Christian. When I mentioned to the second grade teachers that I would like to assess a few children who were having troubles with comprehension Christian's teacher immediately knew whom she wanted me to work with. She thought of Christian right away because she was very puzzled by his reading behaviors. She was pleased that Christian could read at a third or fourth grade level in November of the second grade, but was confused by his inability to understand or respond to the readings he did in school. Through my meetings with Christian, I confirmed the teacher's assessment of his reading.

Christian is a bilingual student whose mother wants him to learn to read in both Spanish and English. However, the school he attends has an English as a second language program whose goal is to move students as rapidly as possible into the mainstream Englishspeaking classrooms. With no support for his Spanish learning at school, his mother has taken responsibility and has Christian do worksheets in Spanish nightly.

In addition to his Spanish work, Christian takes his schoolwork very seriously. $\mathrm{He}$ told me very matter of factly that the reason that he reads is because "I am in second grade." His succinct statement demonstrates his understanding that each grade level has specific expectations and Christian does what he is expected to do. Indeed, when I asked him why people read, Christian's answer was, "because kids go to school." It was as if Christian saw school as his duty and the reading was just a part of the responsibility that went with the job.

Christian's short and serious commentary continued when I asked him to tell me about his experiences with reading, and he replied, "I read fifteen minutes at home everyday." Again, though brief, this comment revealed much about Christian's attitude towards reading, for he stressed timing as a key factor in his experience, emphasizing minutes more than meaning making.

Christian seemed to be watching the clock in our interview. Although he was animated about video games when I asked about his favorite thing to do. He was reserved for the rest of the interview. It seemed that he did not understand why I was asking these questions about reading with such obvious answers. When I asked him what reading was, he was silent and pensive for a moment and then just shrugged his shoulders. Most of his answers about reading reflected that he reads because that was what he was supposed to do. He seemed to be wondering, "Why all the fuss?!"

In reading the third grade level texts Christian flew through the words. He could decode just about any word that was put in front of him. His accuracy rate was excellent $(98 \%)$ and his self-correction rate was understandably low, for there was little to correct. Yet, there was one outstanding feature of Christian's reading that could not be gleaned from 
the numbers and a closer look at his miscues revealed the same. Christian was not using expression to read. In fact, it seemed that he attacked each word, one at a time, in an effort only to get to the next word. "This is the MOST prevalent issue in reading for second language learners of English." (Escamilla, Personal Communication).

\section{Table 2}

\begin{tabular}{ll}
\hline \multicolumn{1}{c}{ Text } & \multicolumn{1}{c}{ Christian's reading } \\
\hline $\begin{array}{l}\text { Then he traced his way back to } \\
\text { the entrance }\end{array}$ & $\begin{array}{l}\text { Then he tra -sed his way back to the } \\
\text { en (pause) trance }\end{array}$ \\
\hline
\end{tabular}

Though Christian was able to decode these words he did not put them back into the context by rereading the sentence or rereading a phrase to attempt to make it make sense to him. In this example he was willing to let the meaning go in order to continue on the decoding path he was so intently following.

Second language learners frequently read one word at a time and even though they read "fluently," and pronounce words correctly, they still lack the deeper knowledge of the English language needed to understand that phrases (multiple word groupings) as well as individual words make meaning. (C. Escamilla, Personal Communication, 2000).

The connections that linked word to word, idea to idea, were missing in this reading. Christian proved to be relying mainly on visual cues to decode text.

His oral reading of the narrative continued to reflect his strong reliance on the visual aspects of text with little attention to the meaning. The following are the only times he did self correct for meaning.

Table 3

\begin{tabular}{cl}
\hline$\underline{\text { Text }}$ & Christian's reading \\
\hline Third graders & Third gran/graders \\
Four groups & Four grops/groups \\
\hline
\end{tabular}

On other occasions he did not correct for meaning.

Table 4

\begin{tabular}{ll}
\hline \multicolumn{1}{c}{ Text } & \multicolumn{1}{c}{ Christian's reading } \\
\hline Chimps groom & Chimps grum \\
Cats pace in front of the glass & Cats pack in front of the glass \\
\hline
\end{tabular}

As these texts had no illustrations to help Christian put the meaning together he had to rely on context, structure and visuals from the text to read. These examples point to the need to build up Christian's vocabulary in order to help him with comprehension.

In looking specifically at his comprehension through the retelling and question tasks, he had great difficulty with answering questions on any oral or listening passage. The 
retellings varied depending on the amount of background knowledge he brought to the reading, but none had sufficient details to warrant adequate marks. On a rubric from one to four he scored the lowest mark of one on each of the four passages tested.

Christian proved to be able to use phonic knowledge to decode words to help him read at a level above his grade-level peers. At the word level, Christian would benefit greatly from detailed vocabulary study. Building his vocabulary would enhance his abilities to make meaning of texts and comprehend many types of texts. A study of vocabulary that "encourages children to discuss, elaborate, and demonstrate meanings of new words" through making connections, will greatly enhance his reading comprehension abilities. (Rupley, Logan \& Nichols, 1999, p. 338) Vocabulary instruction suited for Christian would include the visual aspects of words, as this is strength of his that could be built upon. Another way to demonstrate meanings of words might be through acting the words out such as the words groom and pace, which were miscues from his reading. Acting out words might help him to hear and experience words as phrase units in English.

Building vocabulary alone will not improve Christian's reading comprehension. While reading he was focused on the words and not making sense of the text. However, two things might help remedy this approach, monitoring his reading for meaning and reading with expression and phrasing. Learning to read "like talking" will help Christian begin to hear the meaning of the stories he reads as well as the miscues in making meaning. In order to do this he must become aware of punctuation and meaningful phrasing.

Models of adult readers who read with expression might help Christian see the benefits of fluent reading with meaningful phrasing. Listening to an adult who could model reading with expression might also help him to know how fluent readers sound. Discussion around how reading with expression brought the text to life could greatly enhance Christian's awareness to how fluency can help his comprehension. To extend this learning he could use a tape recorder to tape his own progress. A final exemplary reading could go in the listening center for others to hear. This goal would give Christian a real reason to practice reading for fluency and phrasing and the entire learning community could benefit from his efforts.

The final strategy that would greatly improve Christian's performance in reading comprehension is questioning. Questions are one way good readers monitor meaning while reading. As Christian is taught how to ask questions of himself while reading he will learn to monitor for meaning. Learning to ask questions about things that he is genuinely curious about would help Christian focus more on the meaning, rather than the minutes of word-byword decoding.

Kayla. Kayla is another example of how complex and unique readers can be. When Kayla told me that she liked to read because "you can paint a picture in your head," she showed a glimmer of the fantastic, magical element of linking books with your own imagination. Although this answer a link to making meaning, most of her responses tied reading to a school related activity. When I asked her about reading the first thing she said was, "We have to read for an hour every night." It was not until I pushed her for extended reasons that she arrived at the imagery of painting pictures.

Throughout our conversation she showed an understanding that people read for many different purposes. This third grader mentioned that people read for enjoyment, to study, to 
prepare for teaching children (her aunt is an elementary school teacher), to learn new things, and to look up meanings of words in the dictionary. She also seems to understand that authors write texts to convey a message. Yet when I asked her why, in general, do people read she exclaimed, "Because it makes you smarter, it makes you know more." And finally when I asked her why she reads she said, "I read just to be good at reading." Although she has an idea of the many purposes for reading it seems the one that stands out for her is reading as a means to improve her reading skills.

I found from the running record that Kayla, a third grader, was able to read first grade texts at instructional level $(85 \%$ \& $92 \%)$. Kayla's reading was fluent, but her miscues and errors point to specific problems. When Kayla read, she read very quickly and read right through the punctuation. Fluent reading is a plus when students are using correct phrasing in meaningful units, but this was not the case for Kayla. Much of the time she was stringing sentences together without attention to the punctuation.

The other pattern I saw in her oral reading was that some of the words she attempted did not make sense at the sentence level. Her monitoring for meaning and self-correction were inconsistent. She did self-correct some errors, but other attempts were left uncorrected.

Table 5

\begin{tabular}{ll}
\multicolumn{1}{c}{ Text } & \multicolumn{1}{c}{ Kayla's Reading } \\
\hline $\begin{array}{l}\text { Every time the people left without } \\
\text { buying the house. }\end{array}$ & $\begin{array}{l}\text { Ever/SC time the mouse left with buying } \\
\text { the house }\end{array}$ \\
\hline
\end{tabular}

It seemed that Kayla had limited strategies for decoding text. When asked what she does when she gets to words that she doesn't know she said, "Sound it out, or study it a long time... Then ask your teacher. They're better at sounding out than children." From this statement it is evident that she doesn't feel confident to independently decode words.

Most of the problems above were noted from observable behaviors during Kayla's read aloud. In order to get a sense of her level of comprehension I asked her to retell the story. Even though the miscues and behaviors while reading would indicate that she would not be able to comprehend, Kayla was able to retell the simple first grade narrative story with detail. The expository text, on the other hand, was much more difficult for her and she was only able to retell the first grade text below a satisfactory level. The listening comprehension task on the third grade level showed the same pattern of behavior. She could recount the narrative with details, but the expository text retelling was only below the average level. It seems she has a structure in tact for narrative stories, but not for nonfiction.

Although Kayla has a fairly good concept of what reading is, she is two grade levels behind in her independent level of reading. She needs some help in order to catch up to her grade level peers, as well as, be successful in her content area studies. In third grade the content areas are mostly taught, at this particular school, with textbooks written at a higher level of text than Kayla could read independently.

Since it seems that a main problem of comprehension lies in understanding expository texts, it is important to teach Kayla the nature of these texts. Non-fiction as a 
genre has specific characteristics that can be explored and understood to bring a purpose and idea of what to pay attention to before, during, and after reading.

Immersing Kayla in non-fiction texts and talking about the characteristics of text (i.e. print, labels, captions, graphic elements and text styles) would give Kayla new awareness in order to approach these types of texts more effectively. Awareness of the structure of nonfiction texts and knowledge of how to link background knowledge to information in these texts would help Kayla to connect to non-fiction texts, as she already does with fiction.

Just as Christian, Kayla would benefit from practicing her phrasing and learning to use punctuation to fluently read meaningful units of language. Informal coaching in a reading conference on how to use punctuation during reading would heighten her awareness of punctuation. Once her awareness is heightened, practicing in meaningful, authentic ways would help her to put the strategy to use. Acting out a story is an excellent way to practice fluent reading, with meaningful phrasing. In order to get the character's point of view and emotion across to the audience, fluency and phrasing are key to reading and acting. Through practicing in authentic ways, Kayla will be able to see the effects of dramatic reading and transfer this into her independent reading.

Mark. Mark is an athletic third grade boy who would rather be playing basketball, football, or baseball than doing most any schoolwork. He is diagnosed with Attention Deficit Disorder and takes Ritalin to help him concentrate during school hours. He is having some trouble with schoolwork in third grade. Mark is reading about a year below grade level and having difficulties comprehending what he reads.

Mark has a definite idea of how he can improve all areas of school. He believes the key to improving all his schoolwork is through becoming a better reader. Through our interview he volunteered names of students who he admired in class. He looked up to two boys because they could read chapter books. Mark's aspirations were to read chapter books as well.

Mark has a family that values reading. He showed enthusiasm for trips to the media center with his class where he could get chapter books. Mark was the only child I interviewed who spoke of how his parents would take him to the public library in town where he could also check out "chapter books." He knows where to get books, but still sees reading as a school task that will mainly help him improve in his subjects.

When I asked Mark what reading is he claimed "a way to get better at it." When I asked why do people read, he replied, "So they can get better at it." Mark's main view of reading is a means to improve as a reader. When I asked what he liked about reading, it was the pictures he recalled. Mark maintains a good attitude even though he is a year below grade level. When I asked if there was anything that he didn't like about reading his response was simply, "no."

Mark can describe many strategies that he believes would help a struggling reader, but during his reading these strategies were nowhere to be seen. For example, Mark skipped entire lines of text without notice. He was also reading through punctuation causing him to loose meaningful units of language which could help drive his reading and aid comprehension. His few rereads pointed to limited monitoring for meaning. 
Mark, like Kayla and Christian read right through the punctuation. Reading with fluency and phrasing is the second strategy that Mark needs to use in order for meaning to drive his reading. This can be developed through modeling and discussion about how to read with fluency and expression.

\section{$\underline{\text { Discussion }}$}

The purpose of the study was to see how children having trouble with comprehension perceive reading. These children's perception of reading may be contributing to their comprehension problems. The children viewed reading as a means to improve their skill in reading, rather than for enjoyment and enrichment. They expressed that reading was something that they were required to do in school and not necessarily something they do for meaning and understanding. This is an exploratory study that indicates the need for further investigation into perceptions of reading. This line of research may open inquiry into the relation between what a student generally understands reading to be and comprehension difficulties. This link may have implications for preventing comprehension difficulties and teaching students with comprehension problems.

The findings of this study indicate that children with comprehension difficulties may need help in the acquisition phases of reading in order to grasp the general purpose of reading as meaning making endeavor. From this study we find that assessing children's perceptions of reading may be as important as assessing what they know about reading.

A school librarian has an important role in developing student's perceptions of reading as a meaning making process. Activities that can be accomplished through the library program center on introductions to all kinds of texts including non-fiction as interesting and useful for a variety of purposes. Libraries provide opportunities for children to choose books out of interest and provide them with introductions to books that they might not ordinarily choose on their own. Opportunities to explore different genres serves to broaden students' reading (like Kayla) who are only familiar and comfortable in narrative texts.

School libraries engage students in discussions that center around deeper meanings in texts. Discussions that open up questioning to the students, provides practice in a comprehension strategy, which can help readers to monitor their own reading (Dole, J.A. et al., 1991). In addition, discussions around texts can draw attention to difficult words found in the text to develop expanding vocabulary.

Collaboration between teachers and librarians is necessary for planning inquiry units to expose children to meaningful literacy practices. Close contact with teachers is important for librarians in order to know levels of children's readings so that they can provide materials that the children can read.

Discussion and play-acting about meaning in text would benefit all children, but is especially helpful to those with poor comprehension. These activities encourage monitoring for meaning, reading with fluency and expression and reading meaningful units of print. All of these activities and uses of the library can help to build children's understanding of reading as an enjoyable and meaningful activity that can enrich their lives. 
Teachers and librarians can help children experience the joy of reading as an important aspect of literacy learning. There are differences between good readers' and poor readers' perceptions of reading. The students in this study saw reading as an exclusively a school-related skill. Through discussions around texts that make them aware of the enjoyment and connections to their lives, they begin to find applications to their own reading. A library program that focuses on the deeper meanings of texts during reading may help children with comprehension difficulties to learn to perceive reading as a process of making meaning. This study indicates that the goal of consciously empowering students with the gifts and rewards of reading may be accomplished through collaboration between school librarians and teachers.

\section{REFERENCES}

Borko, H., \& Eisenhart, M. (1986). Student's conceptions of reading and their reading experiences in school. The Elementary School Journal, 86 (5), 589-610.

Burke, C. L. (1980). The reading interview, In B. P. Farr \& D. J. Strickler (Eds.), Reading Comprehension: Resource guide. Bloomington, Indiana: School of Education, Indiana University.

Clay, M. M. (1993). Reading recovery: A guidebook for teachers in training. Portsmouth, N's: Heinemann.

C..y, M. M. (1991). Becoming literate: The construction of inner control. Portsmouth, NH: Heinemann.

Cunningham, J. (1993). Whole to part reading diagnosis. Reading and Writing Quarterly: Overcoming learning difficulties, 9, 31-49.

Dole, J., Duffy, G., Roehler, L., \& Pearson, P. D. (1991). Moving from the old to the new: Research on reading comprehension instruction. Review of Educational Research, 61, 239264.

Edwards, L. (1958). Reading from the child's point of view. Elementary English, 35, 239241.

Fereirro, E., \& Teberosky, A. (1982). Literacy before schooling. Portsmouth, NH: Heinemann.

Harste, J. (1978). Understanding the hypothesis, it's the teacher that makes the difference, Reading Horizons, 18, 32-43.

Johns, J. L., (1974). Concepts of reading among good and poor readers. Education, 95, 5860.

Johns, J. L., \& Ellis, D. W. (1976). Reading: Children tell it like it is. Reading World, 16, 115-128.

Leslie, L., \& Caldwell, J. (1995). Qualitative reading inventory-II. New York: Harper Collins.

Long, R., Manning, M., \& Manning, G. (1985). High and low achieving first-grade readers' perceptions of the reading process, Paper presented at MSERA Annual Meeting, Biloxi, MS. Miller, S. D., \& Yochum, N. (1991). Asking students about the nature of their reading difficulties, Journal of Reading Behavior, 28 (4), 465-485.

Rupley, W., Logan, J., \& Nichols, W. (1998). Vocabulary instruction in a balanced reading program. The Reading Teacher, 52, 336-346. 